\title{
Accounting Perspective in Hospital
}

\author{
https://doi.org/10.3991/ijoe.v16i08.14721 \\ Meiryani $\left({ }^{\bowtie}\right)$, Gatot Soepriyanto, \\ Bina Nusantara University, Jakarta, Indonesia \\ meiryani@binus. edu \\ Dianka Wahyuningtias \\ Bina Nusantara University, Jakarta, Indonesia \\ Kartika Dewi \\ Bina Nusantara University, Jakarta, Indonesia
}

\begin{abstract}
The hospital is an organization whose main purpose is to provide services in the form of examinations, treatment, medical measures and other diagnostic measures needed by each patient within the limits of technological capabilities and facilities provided by the hospital. In addition, the hospital also provides consulting services that provide information and advice to patients. Hospitals in carrying out operational and investment activities are inseparable from the costs. Various kinds of services in hospitals incur costs. Transaction cycle in Hospital: (1) Revenue cycle related to providing hospital services to patients or other parties and receiving patient payments or bills from other parties; (2) The expenditure cycle is related to the procurement of goods and/or services from other parties and the settlement of debts and obligations; (3) Production/service cycle related to the transformation of hospital resources into hospital services; (4) Financial cycles related to the acquisition and management of capital funds (capital funds), such as working capital (sources of cash funds or other liquid funds) and long-term funding sources; (5) The financial reporting cycle is not related to the operating cycle as the first four cycles above. This cycle obtains operating and accounting data from another cycle and processes them into financial statements in accordance with generally accepted accounting principles.
\end{abstract}

Keywords-Accounting, Perspective, Hospital, Decision Making, Accounting Information.

\section{$1 \quad$ Introduction}

The cost accounting system is designed to determine the most actual health care costs. The cost accounting information will be a tool to support cost management through optimal allocation of resources to maximize capacity utilization, and to support a continuous quality improvement process. Aleksandra Szewieczek (2014) cost accounting systems fulfill a number of functions, among which the most important 
are: information, evidence, reporting, control, and analytics. Hospital accounting is one of the activities of financial management is one of the first targets that must be improved in order to provide data and information that will support Hospital managers in decision making as well as monitoring and controlling Hospital activities. The obstacle in Swadana Hospital and it has not been resolved until now is that the Hospital conducts two recording and reporting systems, which are based on the usual accounting principles (Accrual Basis) and Cash Basis (Cash Basis) to meet the applicable provisions which are expected to run in a manner parallel, independent and created a mechanism of mutual control between them (internal control), but felt to be a burden on Hospital staff.

Accounting is a system which is one of the main activities in financial management consists of recording activities, classify and include all transactions and events in an organization involving finance, so that obtained data or information that is useful for retrieval decision.

The final results of accounting are financial statements in the form of:

a) Balance sheet

b) Financial statements (income statement)

c) Report on financial changes.

Hospital Accounting which is one of the activities of financial management is one of the first targets that must be improved in order to provide data and information that will support the para Hospital manager in decision making and observation and controlling Hospital activities. The constraints on the house Swadana Hospital and has not been solved until now is the Hospital conduct two systems of recording and reporting namely based Common accounting principles (Accrual Basis) and Cash Basis (Cash Basis) to meet the applicable provisions that are expected to run in parallel, independently and the mechanism of mutual control between them (internal control), but felt to be a burden on Hospital staff.

The main function of accounting in hospitals is as a source of information needed for decision making in problem solving and planning for the successful development of the hospital. In general, accounting cannot be separated from the cost (cost), with different cost calculations will produce different cost accounting and also have an impact on different decision making. Thus, for the right decision making and planning success, an optimal hospital accounting system and implementation is needed.

\section{Theoretical Framework}

The assessment of services combined in a uniform group, is very similar in terms of the processes and financial aspects of a medical entity, that is, it requires reliable cost information, to allow for optimal profits. The new approach to cost accounting is to create a flexible and multi-dimensional system, making it possible to identify the causes of costs, planning, control and management. The system designed has a systematic character, but most have adopted standard costs as cost accounting assumptions. In the new system, the following must be noted: 
a) Application of the current cost center division into core and additional activities and the Management Board.

b) Highlighting the perspective of determining the cost of patient care, such as the cost of medicinal products and medical equipment, medical procedures performed and allocating the cost of care in hospitals.

c) Identification, especially for core activity costs, the eight main cost categories (record costs in cost centers are first carried out in part of the eight cost categories and then the next level of detailed analysis in the form of specific principal costs) including:

- Medicinal products (eg drugs, blood, blood products, medical gases).

- Medical and non-medical materials used at one time (eg syringes, catheters, bandages, stitches, office supplies, and cleaning products).

- Various uses of medical products and other unspecified materials (eg beds, small surgical instruments, small equipment for diagnostic testing).

- Fixed assets and intangible assets.

- Human Resources (eg wages from work contracts and civil contracts, and mark-ups on wages, financial benefits in connection with staff work, research costs, health and safety activities, employee liability insurance costs).

- Premises (including costs: rent, depreciation, ongoing operations, repairs and maintenance, insurance, taxes and fees associated with it).

- External services provided to patients, especially those of a medical nature, but also other services such as food.

- Services from other centers for core and additional activity costs.

d) The flexible differentiation of resources between economic resources used and involved is obtained when current use needs arise (eg drugs, medical procedures), and the resources involved must be purchased in advance, to maintain capacity and provide health services (such as human resources, buildings, equipment).

e) Determine the availability of resources theoretically and practically, including direct costs incurred, especially costs associated with the need to ensure access to health care services (eg providing equipment and personnel to meet the requirements of the payer, maintaining access during services, etc.).

The process of making cost system information is carried out using three basic modules (elements), representing one cost accounting system:

- Medical information about patients.

- The financial and accounting system, recording current costs, taking into account the main cost categories presented above.

- Control modules used to determine planned costs, significance of controls and cost management (ie resources, medical procedures, hospitalization, patients, readiness, cost centers, etc.), which are identified and grouped into financial and non-financial data. 


\section{$3 \quad$ Result and Discussion}

\subsection{Fund accounting in hospitals}

Fund accounting applications can also be seen in accounting practices in hospitals. However, it must be realized that not all hospitals are non-profit organizations. Some hospitals are operated as like profit-seeking companies, and some even sell their shares on the capital market. In the case of profit-oriented hospitals, the accounting standards followed are financial accounting standards used for the commercial sector.

In this case discussed how the rules and principles of the use of accounting funds in hospitals in the United States (US). In managing a hospital, it is divided into two, namely:

1. Private hospital managed: In this case, the implementation of accounting developed by the Financial Accounting Standards Board - FASB (Financial Accounting Standards Board) especially in statement no. 117 about Financial Statements for Nonprofit Organizations.

2. Government-managed hospital (public hospital): In this case, accounting is implemented based on accounting standards developed by the Government Accounting Standards Board - GASB (Government Accounting Standards Board).

In accounting for funds for hospitals, the presentation of financial information reports requires the formation of funds (funds) which are divided into two, namely:

1. Unrestricted Fund (Unrestricted Fund): Namely funds that are not restricted in use for a particular purpose.

2. Restricted Funds: Ie funds that are restricted in a particular purpose that usually arises because of requests from external parties who make donations. Whether assets are tied or not depends on the provisions of other parties (donors) who provide financial resources

There is no specific PSAK that regulates accounting standards for hospitals. The most suitable PSAK for the time being is PSAK 45 about non-profit organizations.

Based on PSAK 45, hospital accounting is not based on a funding system, only a single fund. However, the RS's net assets are categorized based on three types:

1. Unrestricted funds

2. Temporary binding funds, namely funds with temporary restrictions

3. Permanent bound funds, namely funds with permanent restrictions

\subsection{Hospital financial statements}

In the hospital financial statements there are four main financial statements produced by the accounting process, namely:

\section{Balance Sheet}


Consists of:

- Assets and debt are classified as:

- Current assets - fixed assets

- Good debt - long-term debt

- Net assets (equity) are classified based on:

- Unrestricted net assets

- Temporary bound net assets

- Net assets are bound permanently

The balance sheet in a hospital does not have a fundamental difference in both the content and the preparation process from the standpoint of accounting science compared to the company balance sheet that we often know in the commercial sector, but there are some things that are especially noteworthy:

a. Cash: The amount of cash recorded in the balance sheet does not include cash in the Bound Funds that cannot be used for operating activities.

b. Accounts Receivable: Receivables must be reported at the estimated amount that can be realized.

c. Investation: The initial investment is recorded at cost at the time of purchase, or at fair value at the time of receipt if the investment is received as a gift.

$d$. Fixed assets: Fixed assets are reported together with the accumulated depreciation in the General Fund.

e. Allowance for Assets: The classification of restricted assets is only given to funds whose use is restricted by external hospitals that sponsor the funds.

f. Long-term debt: Long-term debt is reported on the balance sheet.

g. Fund Balance: In accordance with the rules of distribution of funds explained, the balance of funds held by the hospital is separated into three types, namely: bound, temporarily bound, and permanently bound.

\section{Operations report}

For hospitals, the results of their operations are reported in a Statement of Operations. This report covers income, expenses, profit and loss, and other transactions that affect the balance of funds during the period. In the operating report, a performance indicator must be stated as well as net income in the company, which reports the operation of the hospital during the current period. These performance indicators must include both operating profit or loss during the period as well as direct profit obtained during the operation. Other changes in fund balances during the period must be reported after performance indicators.

Here are other posts that also need attention:

a. Patient Services Revenues: Patient service income is calculated from the gross amount using standard rates. This amount is then reduced by contractual adjustments to Net Patient Services Revenues. 
b. Contractual Adjustment: Contractual adjustments stem from the involvement of third parties in the medical reimbursement process. Insurance companies usually reimburse less than the full standard amount for medical services provided to patients who are covered by insurance. Even though the hospital has a standard rate for services rendered, it enters into a contract with a third-party payer where the hospital receives a lower payment amount for the service.

c. Income from Other Activities: Income from other activities reflects income from non-patient sources, such as canteens and parking leases. This income usually reflects the net amount of operations, so not the gross amount.

$d$. Transfer between: It is not appropriate to continue to manage assets in the Binding Fund when the requirements set by the sponsor or donor are fulfilled. In this case the asset must be transferred from the Binding Fund to the Unrestricted Fund. For the purpose of financial reporting, these transfers between funds are reported in the Operational Report as "Waiver of the Fund Balance" and are shown as an addition to the Unrestricted Fund.

Example of Revenue:

1. Outpatient operating income: general ticket and specialist ticket.

2. Inpatient operating income: accommodation and visa.

3. Income medical measures: medical measures, and nursing actions

4. Supporting operational unit income: raciology, laboratory, physiotherapy, pharmacy, and medical rehab.

e. Burden of General Funds: Expenses in the General Fund are recognized on an accrual basis, as is the case for commercial entities.

Example load:

- Service costs: materials, services, employees, depreciation, maintenance, insurance, subscriptions and resources, training, and research.

- General and administrative costs: employees, office administration, depreciation, maintenance, subscriptions and resources, training, and research.

f. Donations: Donations (donations) are divided into donations that are formed in the form of services and assets. Because it is often difficult to determine the value of donations in the form of services, the value of these donations is usually not recorded. However, if there is a need for recording, the estimated value of the service donation is recorded as a contribution which is immediately followed by an equal amount of expense. While donations in the form of assets are reported at fair value on the date they are received as donations if the donation of these assets is restricted by the sponsor or donor, then they are reported in the Temporary Binding Fund or Permanent Binding Fund. When the restrictions are no longer valid, a transfer is made from the Binding Fund to the General Fund.

\section{Report on Changes in Net Assets}

This report presents changes in the three categories of net assets that are not bound, temporarily bound and permanently bound. 


\section{Cash Flow Statement:}

The format of this report is similar to that used for commercial entities.

The cash flow statement consists of: (1) Operating activities; (2)Investment activities; (3)Funding activities.

\section{Notes to the Financial Statements consists of:}

1. General description of the hospital

2. Summary of accounting policies

3. Explanation of financial statement items

The Directorate General of Medical Services of the Ministry of Health makes accounting provisions, especially for hospitals that have become BLU (Public Service Agency). This hospital accounting guideline contains 10 chapters:

1. Introduction

2. Financial Reports

3. Accounting for Assets

4. Accounting for Obligations

5. Accounting for Net Assets (Equity)

6. Accounting for Changes in Net Assets

7. Cash Flow Statement

8. Notes to the Financial Statements

9. Illustration of Financial Statements

10. Financial Ratios

\subsection{Benefits of hospital accounting}

The main function of accounting in hospitals is as a source of information needed for decision making in problem solving and planning for the successful development of the hospital. In general, accounting cannot be separated from costs (cost), with different cost calculations will produce different cost accounting and also have an impact on different decision making. Thus, for the right decision making and planning success, an optimal hospital accounting system and implementation is needed.

The Government Hospital accounting system aims to provide control and oversight of the running of hospital finances, moreover the Hospital has now been designated as a Non-Tax State Revenue (PNBP) or as a Public Service Agency whose receipts must be deposited to the State through the State Treasury Office. And help in monitoring efforts to improve the development of performance and value of the Hospital.

\subsection{Hospital Accounting Implementation}

Government Hospitals are work units of Government Agencies that provide health services to the general public. The financial system of the Hospital has undergone a change as a whole. It is expected that the funds managed by the Hospital will become 
larger and continue to increase in line with the increase in Non-Tax State Revenues (PNBP) and the preparation of the Public Service Agency from year to year.

This condition in addition to having a positive influence on service improvement, also opens opportunities to avoid abuse in the management of state finances. Hospital Accounting which is one of the activities of financial management is one of the first targets that must be improved in order to provide data and information that will support Hospital managers in decision making as well as observation and control of activities within the Hospital. The unresolved obstacle in the Hospital to date is that the Hospital conducts two recording and reporting systems, which are based on the usual accounting principles (Accrual Basis) and Cash Basis (Cash Basis) to meet the applicable provisions which are expected to run in parallel, independently and created a mechanism of mutual control between them (internal control), but this is felt to be a burden for Hospital staff.

In its application the Government Hospital uses the Cash Base or Stelsel Cash System, which is a system that only records "receipts" from spending money, so that this system is actually very simple, easy to work on and does not require high expertise. In addition, supervision becomes easier. Receipts will be recorded if money and expenses have been received within the specified fiscal year. And using the Accrual Basis System, which is a system of transactions and events recognized at the time of the event, not when the rights are received or paid, and recorded and reported in the relevant period. In other words, income is recognized when the services are rendered, not when cash is received; and costs are recognized when incurred, open when cash is paid. With the actual method, assets are recognized when ownership is obtained.

The Government Hospital in managing its finances uses an accounting system whose end result is a financial report. Although the Government Hospital is socially oriented or non-profit, but with the change to a self-financing unit, seeking business profits is important even though it is not the main objective of the establishment of the Hospital. The Government Hospital uses the Business Results Report in reporting the results of its business, but unlike other business entities or hospitals in the form of PT, in Swadana Hospital no part is submitted to the owner as dividend.

Making a Balance Sheet is also called a statement of financial position that shows the condition or financial position of an entity on a certain date. What is meant by financial position is: position of assets or assets, liabilities and capital. In making a hospital balance sheet, it uses two approaches namely the expenditure approach and the resource approach. After that, a Hospital Cash Flow Report is made which contains information about cash flows / cash equivalents in and out during a certain period that comes from operating activities, short-term investments and funding. Which aims to assess the organization's ability to generate cash in the hospital and assess the need for cash outflows. Because by reading the cash flow statement can be known the amount of cash generated in a period, how much comes from operational activities, investment and funding, how much cash is issued to suppliers, employees, paying interest, loan repayments and how the SHU with receipts and expenditures cash. 


\section{Conclusion}

The needs and benefits of accounting in this modern era is no doubt that every company engaged in any field would require the services of people who can apply accounting knowledge to activities according to their fields. Hospital accounting system aims to provide information that is very important in making decisions for successful problem solving and decision making and planning, especially now that Hospitals have been designated as Non-Tax State Recipients or as Public Service Bodies whose receipts must be deposited to the State through the State Treasury Office.

\section{Acknowledgement}

This work is supported by Research Technological Transfer Office (RTTO) BINUS University 2020 funding, as a part of Research Grant of Penelitian Internasional Binus (PIB)/ International Binus Research (PIB) entitled "Quality of Accounting Information Systems and Their Emerging Contributions of Public Listed Companies".

\section{References}

[1] Artur Strzelecki \& Mariia Rizun. 2020. Infodemiological Study Using Google Trends on Coronavirus Epidemic in Wuhan, China. International of Online and Biomedical Engineering iJOE-16(4);139-146. https://doi.org/10.3991/ijoe.v16i04.13531

[2] Aleksandra Szewieczek, 2014, Cost Accounting System Evolution in Health Care Organizations - Current State and Perspectives.

[3] Cleverley. 1982. Handbook of Health Care Accounting and Finance. Aspen System Corporation, Maryland. USA Horngren.

[4] Henni Djuhaeni. Hospital Accounting.

[5] Foster, flat. 2000. Cost Accounting A Managerial Emphasis. Prentice - Hall Inc. New Jersey. USA Kieso, Weygandt, Warfield. 2001. Intermediate Accounting. John Wiley \& Sons, Inc. The USA.

[6] Director General of Yanmed Ministry of Health Republic of Indonesia. "Hospital Accounting Guidelines". Jakarta. 2002.

[7] Gapenski, Louis C. "Understanding Healthcare Financial Management, Fifth Edition". Health.

[8] Gani, Ascrobat. 1994. Independence of Health Efforts (Health Economics Perspective. Jakarta: FKM UI.

[9] Gani, Ascrobat. 1997. Hospital Cost Analysis (Key Guidelines in Hospital Cost Analysis). Presented in the Training of Preparation of Government Hospital Tariff Patterns within the Directorate General of Medical Services Budget Year 1996/1997. Cisarua: Bogor.

[10] Administration Press, 2006. Griffin, Ricky W. and Ronald J. Ebert, 1996. "Business, Prentice Hall International". Edition, United State of America. pdfMachine. Haryono, Jusup.2005. "Fundamentals of Accounting: Volume 1, Issue 7". Yogyakarta: STIE Hefniy. 2008."Management in Islamic Perspective" https://hefniy.wordpress.com/2008/10/06/ management-in-perspectiveislam/. 
[11] Ikhsan, Arfan, Dharmanegara, and Ida Bagus Agung. 2010. Hospital Accounting and Financial Management, Issue 1. Yogyakarta: Graha Science, 2010.

[12] Meiryani. 2016. Influence of uncertainty and risks on the information systems. International Business Management 10(9), pp. 1713-1719.

[13] Meiryani. 2018. The Factors that affect the quality of accounting information systems empirical testing in the state-owned enterprises. Journal of Theoretical and applied information technology 96(7), pp. 1858-1867.

[14] Muftin, Dewi.2013. Analysis of Inpatient Accounts Receivable Management at the Regional General Hospital (RSUD) Dr. Saiful Anwar Malang. Thesis (Unpublished). Faculty of Economics of UIN Maulana Malik Ibrahim, Malang.

[15] Nowicki, Michael. The Financial Management of Hospitals and Healthcare Organizations, Fourth Edition. Health Administration Press, 2007.

[16] Thabrany, Hasbullah. 2009. Determination and Simulation of Hospital Rates. Jakarta.

[17] Rogerio Dionisio,Sergio Malhao, Pedro Torres. 2020. Development of a Smart Gateway for a Label Loom Machine using Industrial IoT Technologies. International of Online and Biomedical Engineering iJOE. 16(4);6-14.https://doi.org/10.3991/ijoe.v16i04.11853

[18] Sabarguna, Boy S. "Hospital Financial Management". Yogyakarta: Consortium of Central Java Islamic Hospital, 2007.

[19] Qurban A Memon \& Mohammad E Hassan. 2020. Cluster Analysis of Patients' Clinical Information for Medical Practitioners and Insurance Companies. International of Online and Biomedical Engineering iJOE-16(4);128-138. https://doi.org/10.3991/ijoe.v16i04. $\underline{13119}$

\section{Authors}

Meiryani is lecturer of Accounting Department, Faculty of Economics and Communication, Bina Nusantara University, Jakarta, Indonesia 11480. Doctoral education was completed in 2016 at the UNPAD with Judicium cumlaude. Aside being a lecturer at Binus University, she is also active as a book writer, researcher, consultant in developing accounting / management information systems. Some writings are spread in various indexed international journals and reputable international journals (Scopus). Other books that have been written are Analysis and Design System (2015), Management Information Systems (2015) and Fundamentals of Management (2016), Introduction to Accounting (2018), Accounting Information System (2019). The author can be contacted via: meiryani@binus.edu

Gatot Soepriyanto is lecturer of Accounting and Finance Department, Faculty of Economics and Communication, Bina Nusantara University, Jakarta, Indonesia 11480.

Dianka Wahyuningtias is lecturer of Hotel Management Department, Faculty of Economics and Communication, Bina Nusantara University, Jakarta, Indonesia 11480.

Kartika Dewi is lecturer of Finance Program, Accounting Department, Faculty of Economics and Communication, Bina Nusantara University, Jakarta, Indonesia 11480.

Article submitted 2020-03-08. Resubmitted 2020-04-19. Final acceptance 2020-04-20. Final version published as submitted by the authors. 